\title{
Research on College Students' Innovation and Entrepreneurship Education under the Background of Internet Plus
}

\author{
Tang Ping \\ Wuhan Donghu University, School of Mechanical and Electrical Engineering, Hubei, China, \\ 430212
}

Keywords: "Internet plus"; innovation and entrepreneurship education; research.

Abstract: In the era of "Internet plus", the cross-border integration of network and traditional industries is getting deeper and deeper. Only by learning from the successful experience of other countries and our country, relying on the network platform, respecting the students personality, combining with the changes of the times and continuing innovative education means, the college students' innovative and entrepreneurship education can meet the working requirements of "keeping up with the times".

\section{Introduction}

Table 1 M College Students ‘Understanding and Acceptance of Innovation and Entrepreneurship Education Course

\begin{tabular}{|l|l|l|l|}
\hline Content of investigation & Number & $\begin{array}{l}\text { Number of } \\
\text { questionnaires }\end{array}$ & Proportion \\
\hline $\begin{array}{l}\text { Harvest from Innovation and Entrepreneurship Courses } \\
\text { Gaining frontier knowledge through the course }\end{array}$ & 487 & 682 & $71.4 \%$ \\
\hline $\begin{array}{l}\text { Innovation and entrepreneurship courses are related to } \\
\text { Majors }\end{array}$ & 233 & 682 & $34.2 \%$ \\
\hline $\begin{array}{l}\text { Innovation and entrepreneurship course are rich in } \\
\text { content and attractive }\end{array}$ & 187 & 682 & $27.4 \%$ \\
\hline $\begin{array}{l}\text { It is believed that the purpose of starting innovative } \\
\text { entrepreneurship courses is to improve the employment } \\
\text { rate. }\end{array}$ & 103 & 682 & $15.1 \%$ \\
\hline $\begin{array}{l}\text { Teachers play an important role in innovative } \\
\text { entrepreneurship curriculum }\end{array}$ & 562 & 682 & $82.4 \%$ \\
\hline $\begin{array}{l}\text { Innovation and entrepreneurship education pay attention } \\
\text { to the practice of professional theoretical knowledge }\end{array}$ & 587 & 682 & $86.1 \%$ \\
\hline $\begin{array}{l}\text { Innovation and entrepreneurship education to enhance } \\
\text { practical operation ability }\end{array}$ & 467 & 682 & $68.5 \%$ \\
\hline $\begin{array}{l}\text { Innovative entrepreneurship education courses provide } \\
\text { legal management knowledge }\end{array}$ & 323 & 682 & 47.4 \\
\hline
\end{tabular}

With the advent of the "Internet plus" era, the integration of innovation and network is becoming more and more close. This has promoted the popularization of new technology applications, 
continuously and effectively enhance the innovation and productivity of the real economy. Relying on the new normal economic development of the Internet has been or is taking shape in various fields. Under the new normal situation, the new Internet education mode has also injected a catalyst into the development of our education industry, especially the innovation and entrepreneurship education reform and deepening. The author conducted a survey on the understanding and acceptance of innovation and entrepreneurship courses for college students. The results of the survey are listed in Table 1.

\section{The inadequacy of innovation and entrepreneurship education in China}

Under the new situation, innovation and entrepreneurship education in China's colleges and universities is proceeding to improve and improve the teaching level and quality, but there are still some problems in the implementation process ${ }^{[1]}$.

Multi-challenges are manifested in:

\subsection{Single content and form of education and teaching}

At present, the content of innovation and entrepreneurship education in Colleges and universities is generally narrow, "mainly reflected in the curriculum system setting does not reflect the cultivation of innovation and entrepreneurship ability, innovation and entrepreneurship curriculum cannot be closely integrated with professional courses, does not really incorporate innovation and entrepreneurship education into the training objectives and training programs, only falls on paper, not really implemented, with education, teaching and science. Research and production need to be seriously disjointed. Lack of entrepreneurship training and entrepreneurial practice training, lack of interactive experience training methods and means, students need to strengthen the learning process of practical innovation.

\subsection{Teachers 'professionalization needs to be improved}

At present, "Colleges and universities lack the subject of innovation and entrepreneurship education, professional leaders and academic backbone. They can only publicize the subject according to the text and talk on paper. Innovation and entrepreneurship education cannot be effectively integrated into education and teaching, and excellent teaching team cannot be formed." Teachers of innovation and entrepreneurship education have not experienced entrepreneurship practice and systematic and professional training. For various reasons, educators do not attach enough importance to innovation and entrepreneurship education, do not have the ability to carry out innovation and entrepreneurship education in accordance with actual conditions, cannot interact with students ${ }^{[2]}$, and cannot effectively stimulate students 'enthusiasm for innovation and entrepreneurship.

\subsection{Educational concepts should not keep pace with the times}

The state has updated, issued and promulgated a series of programmatic documents and requirements for innovation and entrepreneurship education according to the changing situation, but the documents and requirements cannot be implemented in time, resulting in students 'innovation and new ideas cannot be timely docked with reality. At present, the innovation and entrepreneurship education in most colleges and universities is only carried out by means of organizing entrepreneurship plan contest. It can only let individual students participate in the shallow innovation and entrepreneurship lecture education, or only symbolically set up the University 
Students 'entrepreneurship base without playing its role. Because of the shortage of teachers and the change of form, there is a lack of practical guidance education for students.

\subsection{Imperfect reform of personnel training mode}

Because they do not have the ability to integrate resources and construct and implement innovative entrepreneurship education system, universities often fail to incorporate innovative entrepreneurship education into personnel training work, generally fail to form or establish a unified and practical talent training program, and the integration of innovative entrepreneurship education and education and teaching system is insufficient. Most students cannot access the education content related to innovation and entrepreneurship education and cannot receive relevant training. It has become an urgent task for colleges and universities in China to reform ideas, break the traditional model ${ }^{[3]}$, take students as the centre and rely on the network to improve the level of innovation and entrepreneurship education.

3 The new idea of innovation and entrepreneurship education for college students under the background of "Intermet +".

"Innovative talents refer to those who have innovative spirit, innovative consciousness, innovative thinking, innovative ability and can achieve innovative results; while entrepreneurial talents are those who know certain professional skills, possess the qualities of pioneering innovation, organizational communication, entrepreneurs, are good at discovering business opportunities and conducting business activities through creative production or business activities and obtain benefits. Member. " Under the background of "Internet +", through innovation and entrepreneurship education, college students have "innovative spirit, innovative consciousness, innovative thinking" and "innovative ability", and even become "entrepreneurial talents" ${ }^{\text {[4] }}$. It is undoubtedly of great significance to help them smoothly walk out of ivory tower and integrate into society and maintain the development of socialism with Chinese characteristics and even with Chinese characteristics. Institutions of higher learning should actively practice and try to explore ideas, methods and measures to adapt to the new situation based on existing experience.

\subsection{Relying on College Students 'Employment and Entrepreneurship Guidance Course and Combining Practice to Develop Network Education of Innovation and Entrepreneurship}

With the popularity of the Internet, human cognition has been expanding in depth, concept innovation has been pushed forward, and backward models have been eliminated and abandoned. In 2007, Salman Khan set up a non-profit Khan Academy through the network platform to realize the complete innovation of the educational model, "which is opening up the dawn of future education" and let the educates "really realize their own step-by-step learning". Traditional classical theories and models are constantly re-interpreted and recognized by people, and quickly recognized through the network. Innovation and entrepreneurship education are aimed at young people with higher learning autonomy and should actively enhance their innovative ability and foster the awareness of innovation and cooperation. Under the background that the network has become an important stage and carrier of education, colleges and universities should rely on the existing campus network platform, timely enrich and update content and materials, establish corresponding education network system, and promote carrier innovation. New media technology can be used to combine traditional education methods, methods and MOOC and other modern teaching methods to build a more closely linked curriculum system with reality. In the process, we should actively pay attention to the development of business forms and make the latest cases of innovation and entrepreneurship 
become learning materials; we should turn the social hotspots that students pay attention to into educational resources that they can contact; we can also invite elites and experts from the industry to participate in online teaching, expand students 'learning time and space, and through face-to-face exchanges, micro-columns and other forms of interaction. Students are concerned about employment and entrepreneurship.

\subsection{Make use of the network platform to keep the innovation and entrepreneurship education in Colleges and universities up with the pace of social change through sustained innovation}

From blog, microblog, to APP application platform and Weixel, more and more network platforms can be relied on and more convenient to use. Only by adapting to the fast rhythm of the Internet era, innovating continuously and making good use of the network platform creatively, can the innovative education of entrepreneurship give full play to its guiding role. We should pay attention to the universality and penetration of Internet participation. Through fragmentation, interaction, interaction and other means, innovation and entrepreneurship education should go deep into students 'daily life and integrate with it, mobilize students' enthusiasm and initiative, and enhance their participation. When modern enterprises expand their markets, they often rely on the network to attract customers through scenario applications and storylines. Colleges and universities can learn from and properly use the expression of "scenario + story" to reform the traditional teaching mode, take the changing world as the scene, change the situation of all walks of life under the new normal into stories, and carry out in-depth exchanges with students to help them establish the consciousness of innovation and entrepreneurship ${ }^{[5]}$.

\subsection{Establishing a network base for college students 'entrepreneurship and attaching importance to improving the efficiency of innovation and Entrepreneurship Education}

The convenience and intuition of the network are increasingly recognized by the society. The platform has a wide audience and great influence, which can maximize the role of high-quality educational resources. In the process of implementing the docking between innovation and entrepreneurship education and network platform, attention should be paid to the effective sharing and full utilization of resources, which will inevitably effectively enhance the influence of innovation and entrepreneurship education among students. Ebury, Taobao, shooting

Photography, eBay, Jindong and Weidman have become an inseparable part of the life of young college students. Colleges and universities can use these platforms to build business bases and encourage students to participate in the process of innovation and entrepreneurship education.

\subsection{Exploring the possibility of creating more practice platforms and implementing them by utilizing the characteristics of the network era}

Contemporary youth pursue the display of self-worth, and the high openness and wide participation of the network provide a platform for them to show themselves. The "guest" culture represented by blogs, podcasts, flashers, Wiki and creators has further deepened the network culture, and its individualization, diversification and diversification are more obvious. However, the current practice of innovation and entrepreneurship education in China still relies on the "Challenge Cup" and entrepreneurship design competitions, and the participation is not high. Some colleges and universities have launched the innovation and entrepreneurship education training and practice plan related to Internet + related to this situation, which provides a good foundation for expanding innovation and entrepreneurship education. Innovation and entrepreneurship practice should be combined with the needs of network innovation being developed continuously, and with the 
requirements of students 'self-value realization, actively induce students to play their innovative and creative abilities, fully guide and encourage them to participate in innovative and entrepreneurship practice.

\section{Conclusion}

The implementation of the "Internet plus" will undoubtedly inject fundamental transformation forces into the transformation and upgrading of China's traditional industries, and promote the digitalization, networking and intellectualization of the industry. This is the core of China's implementation of the 2025 strategy of manufacturing in China. At the critical stage of deepening the transformation of economic structure and building an innovative country, universities at all levels can only meet the requirements of the party and the government for innovative entrepreneurship education for college students in the new era, to provide more excellent talents for the steady progress of the great rejuvenation of the Chinese nation.

\section{References}

[1] Qiu Jiajia, Wang Rong, Li Xiaokai. Research on the innovation and Entrepreneurship of university students in the capital application Universities under the background of "Internet + " [J]. labor security world, 2017 (33): 3.

[2] Fu Xiangyang, Liu Hailong, Bai Yan Shu. Integration of university entrepreneurship Park and innovation and Entrepreneurship Education under the background of "Internet +" research [J]. Chinese Vocational and technical education, 2017 (19): 55-57.

[3] Cheng Hongli. Implementation strategy of innovation and entrepreneurship education in Colleges and Universities under the background of "Internet +" [J]. Journal of the National Institute of educational administration, 2017 (05): 76-81.

[4] Shen Wen. Problems and Countermeasures of College Students'Innovation and Entrepreneurship Ability Training in the Internet Era [D]. Nanchang University, 2017.

[5] Zhao Zheng, Wang Jieshi, Ding Wang Min. Exploration of innovation and entrepreneurship education in Local Universities under the background of "Internet +": taking 6 universities in Wuhu as an example, [J]. college counselor journal, 2016,8 (03): 64-67. 